


\section{About IJMA [last updated October, $\left.1^{\text {st }}, 2021\right]$}

$\checkmark$ International Journal of Medical Arts is the Official Journal of the Damietta Faculty of Medicine, AlAzhar University, Egypt

$\checkmark$ It is an International, Open Access, Double-blind, Peer-reviewed Journal

$\checkmark$ Published four times a year

$\checkmark$ The First Issue was published in July 2019

$\checkmark$ Published under the following license: Creative Commons Attribution-ShareAlike 4.0 International Public License (CC BY-SA 4.0). It had updated from the Creative Commons license [CC BY] in volume 2, Issue 4, October 2020 About IJMA

$\checkmark$ The Egyptian Knowledge Bank hosts the web site of IJMA

$\checkmark$ The Egyptian Knowledge Bank supports IJMA

$\checkmark$ IJMA follows the regulations of the International Committee of Medical Journal Editors

$\checkmark$ IJMA is indexed in the "Directory of Open Access Journals" [15 January 2021].

$\checkmark$ IJMA is indexed in J-Gate [29-6-2021]

$\checkmark$ IJMA is a member of the International Society of Managing and Technical Editors

$\checkmark$ Listed in "Index Copernicus", "Publons", "Academic resource index [ResearchBib]" "Electronics journal library", "Eurasian Scientific Journal Index", "WorldCat" Superstar Journal Database, and "Citefactor"

$\checkmark$ IJMA introduced to the search engine [BASE] through DOAJ

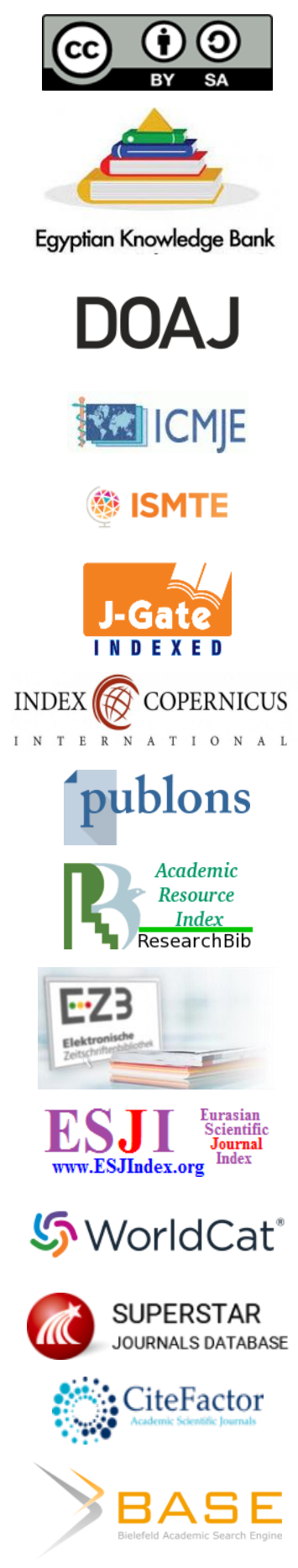




Available online at Journal Website
https://ijma.journals.ekb.eg/
Main subject [Urology]

Original Article

\title{
Laparoscopic Burch Colposuspension versus Transobturator Tape for Female Genuine Stress Urinary Incontinence
}

\author{
Adel Saad Shaltout [1], khaled Mohamed Sabry [2], Mohamed Ahmed Abdelaal [2], Amany Ahmed Soliman [2]
}

1 Department of Urology, Damietta Faculty of Medicine, Al-Azhar University, Egypt

${ }^{2}$ Department of Urology, Faculty of Medicine [For Girls], Al-Azhar University, Egypt

Corresponding author: Adel Saad Shaltout

Email: dr.adelshaltout@domazhermedicine.edu.eg

Submission date: August 22, 2021; Acceptance date: September 14, 2021

DOI: 10.21608/IJMA.2021.83881.1337

\section{ABSTRACT}

Background: Stress urinary incontinence [SUI] is defined as the involuntary passage of urine during activities lead to increased intra-abdominal pressure. The cause is urethral hypermobility or weakness of intrinsic sphincter. It is a common type of urinary incontinence. No consensus was reached for the standard treatment approach.

Aim of the work: The current study aimed to compare the efficacy and safety of laparoscopic [Burch] colposuspension procedure and Transobturator tape [TOT] procedure in the treatment of female genuine SUI.

Patients and Methods: The study included 30 adult females with grade II or III genuine SUI; according to Blavias and Olsson classification. All were assessed by history taking, physical examination, laboratory and radiological investigations. Then, they were divided into two equal groups according to surgical intervention. the primary outcome was symptoms improvement. Secondary outcomes included intra operative and post-operative complications.

Results: The mean operative time in Burch group was longer than TOT group [70.67 \pm 17.48 vs $50.35 \pm 25.54$, minutes respectively]. However, the difference was non-significant. The intraoperative blood loss was $90.48 \pm 31.55$ and 64.57 $\pm 16.22 \mathrm{ml}$, in Burch and TOT groups respectively. The type of continence was mainly of sole stress type [86.7\% and 93.3\% in Burch and TOT groups respectively]. Severe postoperative [PO] pain was reported only by one patient in Burch group. Burch had a significantly lower cost that TOT [155.8 \pm 1.46 vs $344.39 \pm 1.29 \$$, respectively], and there was significant reduction of retention, difficulty, dribbling of urine, intermittency and hesitancy [continence status] among Burch than TOT group. In addition, different unwanted aspects of sexual function were significantly lower among Burch than TOT group.

Conclusion: Laparoscopic Burch colposuspension procedure resulted in significantly favorable outcome regarding cost, continence and sexual function. The complications were comparable between both procedures.

Keywords: Burch; Colposuspension; Transobturator Tape; Stress Urinary Incontinence

This is an open-access article registered under the Creative Commons, ShareAlike 4.0 International license [CC BY-SA 4.0] [https://creativecommons.org/licenses/by-sa/4.0/legalcode.

Citation: Shaltout AS, Sabry KM, Abdelaal MA, Soliman AA. Laparoscopic Burch Colposuspension versus Transobturator Tape for Female Genuine Stress Urinary Incontinence. IJMA 2021; 3 [4] October-December: 1827-1834 [DOI: 10.21608/IJMA.2021.83881.1337].

* Main subject and any subcategories have been classified according to the research topic 


\section{INTRODUCTION}

Stress urinary incontinence [SUI] is defined as a spontaneous involuntary loss of urine, produced as a result of increased intra-abdominal pressure. In addition, the pathological etiology includes urethral hypermobility or muscle weakness of the intrinsic urethral sphincter. It is a commonest type of urinary incontinence, as it accounts for about $50 \%$ of all SUI cases [1]. Two main categories of sphincter abnormality are present; the urethral hypermobility and intrinsic sphincter deficiency [ISD]. However, both types may coexist. Urethral hypermobility is due to a defect in the bladder neck pelvic support, while ISD is recognized as a loss of bladder outlet closure potential [2].

The surgical treatment for urethral hypermobility SUI was significantly reformed in 1995 by the introduction of a new model, the mid-urethral support without tension, invented by Ulmsten and Petros [3].

The open Burch technique was originally introduced in 1961 and it was a major development in the management of SUI. The Burch technique was the gold-standard surgery for female's SUI. It remains an excellent effective choice with relatively lower complications. However, it is technically difficult ${ }^{[4]}$.

The original design of trans-obturator tape [TOT], initially introduced in 2001 by Delorme, was to introduce the tape between the two obturator foramina, from outside to inside. The reported outcome is closer to tension-free vaginal tape [TVT]. No injuries have been reported, increasing the attractiveness in the trans-obturator route ${ }^{[5]}$. Another novel technique was introduced at the end of 2003, by de Leval. It included an inside to outside passage of the tape through the obturator foramina. It is termed tension-free vaginal tapeoutside [TVT-O]. Reported results of TVT-O showed that, it is a feasible, precise, rapid, and simple maneuver. In addition, it escapes the urethral and bladder destruction. Thus, cystoscopy was not necessary [6].

Studies confirmed that the use of a tension free polypropylene mesh leads to high success rates and the SUI therapy become more simplified. The TVT and the TOT are the most common possibilities for the management of SUI [7]. Thus, the different kits have provided to produce the slings. However, its use was limited due to high costs.

In 1991, the first laparoscopic bladder neck suspension was introduced by Vancaille and Schuessler [8]. Like other laparoscopic techniques, there was lower pain, reduced morbidity, shorter duration of stay in hospitals and rapid return to normal daily activities.
Although different previous reports are present about the outcome of TVT, TOT and open Burch techniques in SUI treatment, the prospective randomized studies comparing these procedures are still lacking. Thus, the current study was designed to address this situation.

\section{AIM OF THE WORK}

The current trial aimed to compare the efficacy and safety of laparoscopic [Burch] colposuspension and TOT procedures in treatment of female genuine SUI.

\section{PATIENTS AND METHODS}

This prospective interventional study had been carried out at the departments of Urology, Al-Azhar University Hospitals [Al-Zahraa and Damietta], Egypt. It was completed from March 2020 to March 2021. It included 30 adult females with grade II or III genuine SUI; according to Blavias and Olsson classification, $1988{ }^{[9]}$. The Exclusion criteria included pregnancy, concomitant neurological pathology affecting the bladder, previous history of radio- or chemo-therapy, uncorrectable coagulation disorder, antipsychotic treatment, or urogenital prolapse of more than the $2^{\text {nd }}$ degree according to Baden and Walker classification 1992 [10].

All eligible females were randomly allocated [1:1 allocation ratio] into one of the two treatment group; the first group for laparoscopic Burch colposuspension, and the second group for TOT procedure.

At the preoperative stage, all females were evaluated by full medical history taking, general clinical examination, local pelvic examination including stress test and laboratory investigations [to check their fitness to surgical intervention]. The laboratory workup included complete urine analysis and culture, blood chemistry [e.g., blood urea, serum creatinine, fasting and postprandial blood glucose, liver function tests and coagulation profile], and complete blood cell count $[C B C]$. Furthermore, a pelvi-abdominal ultrasonography to evaluate of the urinary bladder, its capacity and upper urinary tract, was performed. Finally, urodynamic studies in the form of uroflowmetry and cystometry were done. Uroflowmetry aimed to evaluate the maximum and average flow rates, and the pattern of the flow. On the other side, cystometery aimed to evaluate the bladder capacity, Valsalva leak point pressure, and presence of uninhibited detrusor contraction.

\section{Surgical procedures}

Laparoscopic Burch colposuspension: All procedures were completed under general anesthesia. The patient was positioned in a dorsal lithotomy. Briefly, it was completed 
through extraperitoneal approach. Just below the umbilicus, a midline incision was created [about $1.5 \mathrm{~cm}$ ]. The preperitoneal distention balloon [PDB] cannula was introduced towards the pubis alongside the posterior rectus sheath. A laparoscope 10-mm Hasson-style blunt tip balloon trocar was introduced after expansion of the space of Retzius. Two extra $5 \mathrm{~mm}$ trocars were inserted, one in each lower quadrant at a point one third lateral to the rectus muscle. With $\mathrm{CO}_{2}$ insufflation at a pressure of $8-10 \mathrm{mmHg}$, mobilization of the bladder was done with dissection of the periurethral fat from the pubocervical fascia. Then, exposure of the Cooper's ligaments was achieved followed by cleansing of the areolar tissue and fat around the ligaments. One or two non-absorbable sutures were sited at the level of the mid-urethra without penetration of the vaginal mucosa. Then, a tension-free knotting technique was used to fix it to the Cooper's ligament. An intraoperative cystoscopy was done as the final step of the surgery to exclude any urethral or bladder injuries. Twenty-hours after surgery, the Foley catheter was removed, and then intermittent selfcatheterizations were done until the post-void residual urine was $<50 \mathrm{~mL}$ [11].

Transobturator tape procedure: Through a vaginal small incision site and in the femoral/pelvic fold, insertion of a bilateral transobturator mesh by means of needle was achieved. Figures [1] to [11] are describing the surgical procedure.

Post-operative care consisted of vaginal pack for one day, abstinence from sexual intercourse for 4 to 6 weeks, regular vaginal douche for one month, and oral fluoroquinolones and metronidazole for 10 days. Postoperatively the patients were assessed after 1, 2 weeks and 1,3 , months by clinical evaluation, pelvi-abdominal ultrasound and urodynamic study.

\section{The outcome measures}

1. Improvement of symptoms [the primary endpoint]; cure was defined if no SUI occurred postoperatively [the absence of any subjective urine leakage complaint, and the leakage absence on cough, stress testing and urodynamics [negative Valsalva leak point pressure]]. Otherwise, they were considered improved if SUI still present but to a milder degree than pre-operative condition. Failure was documented if the patient still complaining of SUI whether the condition was the same or worse than before surgery.

2. Peri-operative complications: [e.g. bleeding, injuries to the urethra, bladder, vagina, nerves or bowel, urinary retention, hematoma, wound infection, urethral erosions]. In addition, operative time, anesthesia type, post-operative analgesia [type and dosage], and hospitalization time are reported.

\section{Ethical considerations}

The study protocol was introduced and accepted by the local institutional review board [IRB], Damietta Faculty of Medicine, Egypt. In addition, each patient signed a written informed consent. Extreme care was exerted to ensure the safety of participants, and the participant had the full right to withdraw from the study at any time. Data are available on request.

\section{Statistical analysis}

At the end of study, data was collected, coded, fed to personal computer and analyzed by Microsoft Excel and Statistical Package for Social Sciences [SPSS] version 18 [SPSS Inc., Chicago, IL, USA]. Appropriate statistical tests were used to assess association or significance between groups. Treatment efficacy and safety analyses were performed as the per-protocol [PP] population. A two-sided probability value [p-value] of $<0.05$ was considered significant.

\section{RESULTS}

In the current work, there was no significant difference between Burch and TOT, regarding patient age, body mass index [BMI], parity and associated comorbidities [Table 1].

Both groups were comparable regarding operative and postoperative data. The mean operative time in Burch group was longer than TOT group $[70.67 \pm 17.48$ vs $50.35 \pm$ 25.54, minutes respectively]. However, the difference was non-significant. The intraoperative blood loss was $90.48 \pm$ 31.55 and $64.57 \pm 16.22 \mathrm{ml}$, in Burch and TOT groups respectively. The type of continence was mainly of sole stress type [86.7\% and $93.3 \%$ in Burch and TOT groups respectively]. Severe PO pain was reported only by one patient in Burch group [Table 2]. .

The functional outcome, follow up outcome, incontinence and storage functions, revealed non-significant difference between Burch and TOT groups. However, Burch had a significantly lower cost that TOT [ $155.8 \pm 1.46$ vs $344.39 \pm$ $1.29 \$$, respectively]. In addition, there was significant reduction of retention, difficulty, dribbling of urine, intermittency and hesitancy [continence status] among Burch than TOT group. In addition, different unwanted aspects of sexual function were significantly lower among Burch than TOT group [Table 3]. 


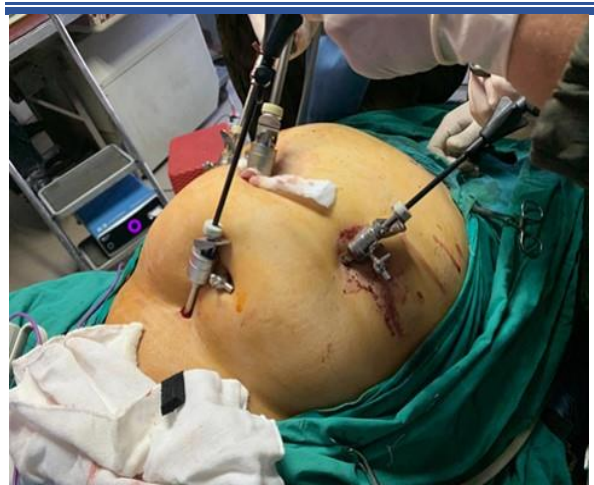

Figure [1]:The patient in dorsal lithotomy position and four ports were placed.

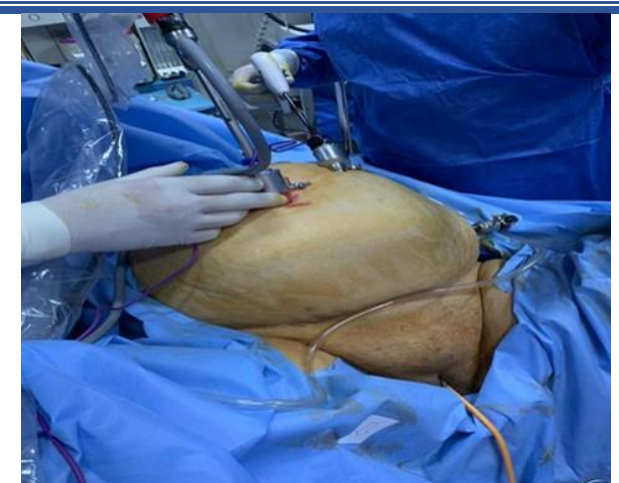

Figure [2]: The patient in dorsal lithotomy position and three ports were placed

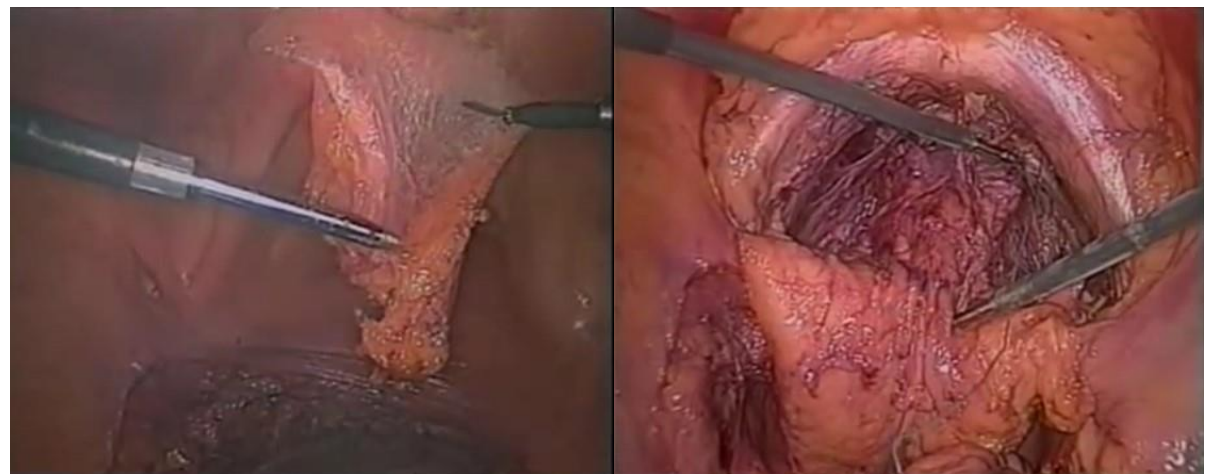

Figure [4]:Identification of loose areolar tissue confirms a proper plane of dissection to enter the space of Retzius

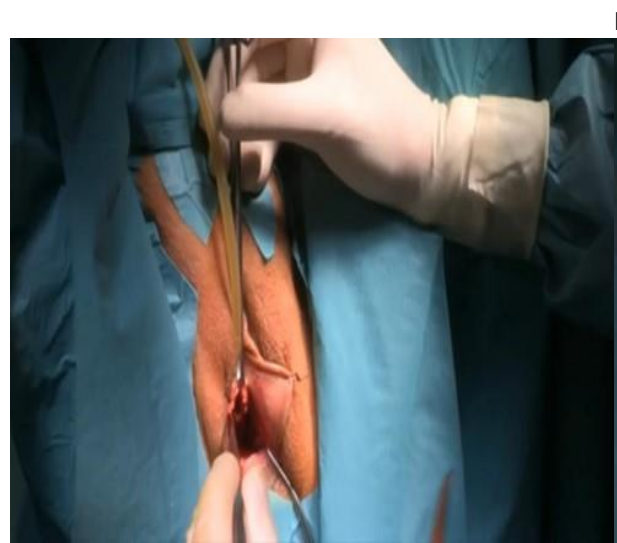

Figure [7]: Suburetheral longitudinal midline incision of anterior vaginal wall inpresence of uretheral catheter.

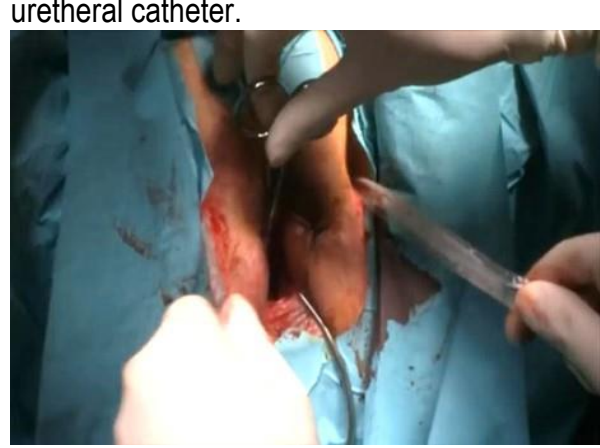

Figure [10]: Suburethral straightening of the tape
Figure [5]: Retropubic anatomy after blunt dissection anterior, transversalis fascia medially symphysis pubis laterally, pubic rami and cooper's ligament

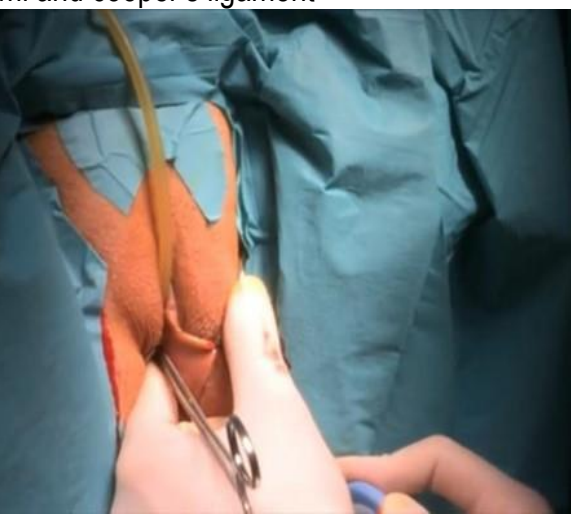

Figure [8]:Tape applicator [needle] passing through tract created using out in technique by supination movement

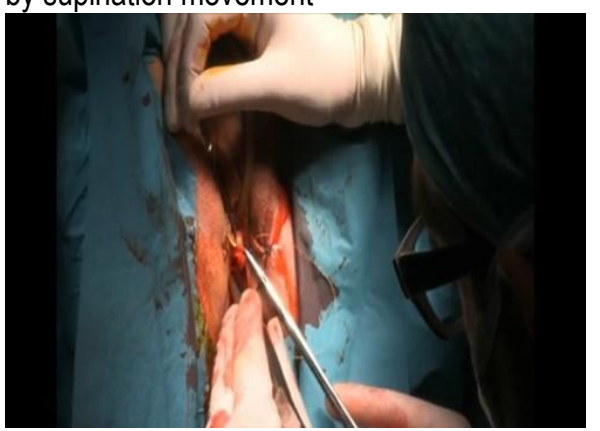

Figure [11]: Closure of vaginal incision by vicryl $3 / 0$ in interrupted manner

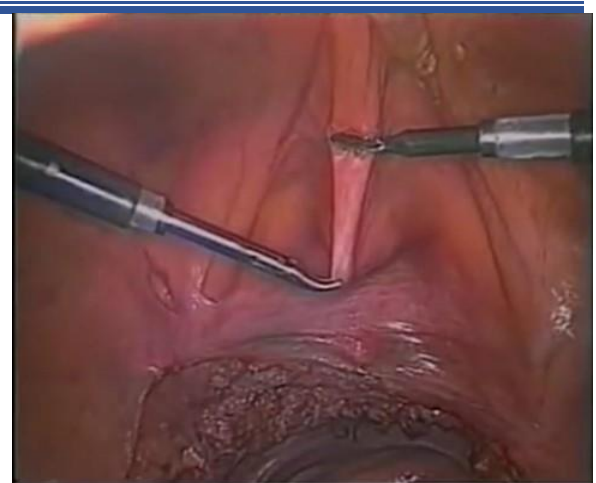

Figure [3]:Peritoneal incision in midline. $3 \mathrm{~cm}$ superior to dome of the bladder between the obliterated umbilical ligaments

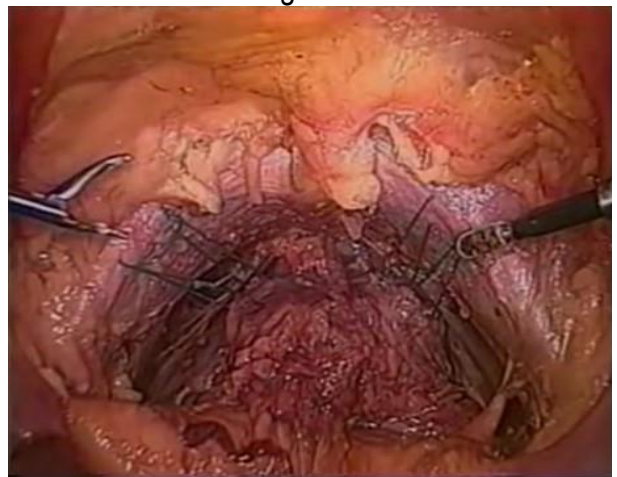

Figure [6]: A 2-0 braided non-absorbable suture [Ethibond] is placed over the para vaginal fascia fixed to cooper's ligament

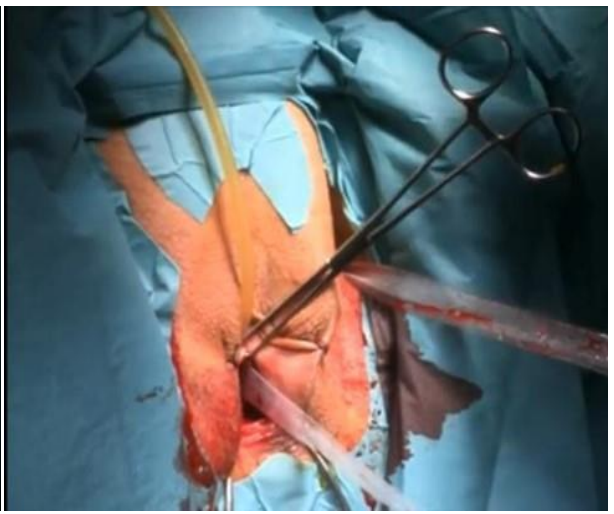

Figure [9]: Mesh was fixed to the needle and drawn out through the thigh by pronation movement 


\begin{tabular}{cccccc} 
& Variables & BURCH & TOT & Test & P \\
& Age [years] & $40.17 \pm 13.01 ; 19-63$ & $41.35 \pm 14.12 ; 22-65$ & 0.23 & 0.81 \\
& BMI [kg/m²] & $30.48 \pm 4.65$ & $29.71 \pm 4.82$ & 0.445 & 0.659 \\
& Parity & $2.64 \pm 0.836$ & $2.84 \pm 0.972$ & 0.604 & 0.551 \\
Comorbidities & Hypertension & $4[26.7 \%]$ & $3[30.0 \%]$ & 0.186 & 0.666 \\
& Diabetes mellitus & $2[13.3 \%]$ & $2[13.3 \%]$ & 0.001 & 1.00 \\
& Prior hysterectomy & $1[6.7 \%]$ & $2[13.3 \%]$ & 0.371 & 0.543 \\
& Hormone replacement therapy & $5[33.3 \%]$ & $4[26.7 \%]$ & 0.159 & 0.691 \\
& Menopausal status & $7[46.7 \%]$ & $8[53.3 \%]$ & 0.133 & 0.715 \\
\hline
\end{tabular}

Table [2]: Operative and postoperative data in both groups

\begin{tabular}{|c|c|c|c|c|c|}
\hline \multicolumn{2}{|c|}{ Variables } & Burch [N=15] & TOT [N=15] & Test & p \\
\hline Operative time [min] & & $70.67 \pm 17.48$ & $50.35 \pm 25.54$ & 0.34 & 0.532 \\
\hline Blood loss [ml] & & $90.48 \pm 31.55$ & $64.57 \pm 16.22$ & 0.21 & 0.435 \\
\hline $\begin{array}{l}\text { Type of urinary } \\
\text { incontinence }\end{array}$ & $\begin{array}{l}\text { Stress } \\
\text { Mixed }\end{array}$ & $\begin{array}{c}13[86.7 \%] \\
2[13.3 \%]\end{array}$ & $\begin{array}{c}14[93.3 \%] \\
1[6.7 \%]\end{array}$ & 0.371 & 0.543 \\
\hline Hospital stay duration [days] & & $0.625 \pm 0.324$ & $1.02 \pm 0.647$ & 1.97 & 0.056 \\
\hline Complications & $\begin{array}{l}\text { Bladder injury } \\
\text { Bowel injury } \\
\text { Wound infection } \\
\text { Erosions } \\
\text { None }\end{array}$ & $\begin{array}{c}2[13.3 \%] \\
0[0.0 \%] \\
2[13.3 \%] \\
0[0.0 \%] \\
11[73.3 \%]\end{array}$ & $\begin{array}{c}0[0.0 \%] \\
1[6.7 \%] \\
1[6.7 \%] \\
1[6.7 \%] \\
12[80.0 \%]\end{array}$ & 4.37 & 0.35 \\
\hline $\begin{array}{l}\text { Postoperative [PO] } \\
\text { pain }\end{array}$ & $\begin{array}{l}\text { Mild } \\
\text { Moderate } \\
\text { Severe }\end{array}$ & $\begin{array}{c}9[60.0 \%] \\
5[33.3 \%] \\
1[6.7 \%]\end{array}$ & $\begin{array}{c}8[53.3 \%] \\
7[46.7 \%] \\
0[0.0 \%]\end{array}$ & 1.39 & 0.499 \\
\hline
\end{tabular}

Table [3]: Outcome among studied populations

\begin{tabular}{|c|c|c|c|c|c|}
\hline & Outcomes & Burch [N=15] & TOT [N=15] & Test & $\mathbf{p}$ \\
\hline \multirow{5}{*}{$\begin{array}{l}\text { Functional } \\
\text { outcome }\end{array}$} & Urinary retention & $3[20.0 \%]$ & 2 [13.3\%] & 0.240 & 0.624 \\
\hline & Recurrent UTI & $1[6.7 \%]$ & $0[0.0 \%]$ & 1.03 & 0.311 \\
\hline & De novo urgency & $2[13.3 \%]$ & $0[0.0 \%]$ & 2.14 & 0.143 \\
\hline & Short-term voiding dysfunction & $2[13.3 \%]$ & $1[6.7 \%]$ & 0.371 & 0.543 \\
\hline & Long-term voiding dysfunction & $1[6.7 \%]$ & $0[0.0 \%]$ & 1.03 & 0.311 \\
\hline \multirow{3}{*}{$\begin{array}{l}\text { Follow up } \\
\text { outcome }\end{array}$} & Cured & $13[86.7 \%]$ & $14[933 \%]$ & & \\
\hline & Improved & $1[6.7 \%]$ & $1[6.7 \%]$ & 1.03 & 0.59 \\
\hline & Failed & $1[6.7 \%]$ & $0[0.0 \%]$ & & \\
\hline \multirow{3}{*}{$\begin{array}{l}\text { Cost [\$] } \\
\text { Incontinence }\end{array}$} & & $155.8 \pm 1.46$ & $344.39 \pm 1.29$ & 3362 & $<0.001^{*}$ \\
\hline & After 2 weeks & $5[33.3 \%]$ & $3[20.0 \%]$ & 0.682 & 0.409 \\
\hline & After 3 months & $2[13.3 \%]$ & $1[6.7 \%]$ & 0.371 & 0.543 \\
\hline \multirow[t]{5}{*}{ Continence status } & Retention & $1[6.7 \%]$ & $4[26.7 \%]$ & & \\
\hline & Difficulty & $1[6.7 \%]$ & $3[20.0 \%]$ & & \\
\hline & Dribbling of urine & $0[0.0 \%]$ & $1[6.7 \%]$ & 14.13 & $0.015^{*}$ \\
\hline & Intermittency & $1[6.7 \%]$ & $3[20.0 \%]$ & & \\
\hline & Hesitancy & $1[6.7 \%]$ & $3[20.0 \%]$ & & \\
\hline \multirow[t]{5}{*}{ Storage } & Frequency & $2[13.3 \%]$ & $3[20.0 \%]$ & & \\
\hline & Urgency & $1[6.7 \%]$ & $3[20.0 \%]$ & & \\
\hline & Nocturia & $0[0.0 \%]$ & $1[6.7 \%]$ & 5.78 & 0.32 \\
\hline & Urgency with fear of leaking & $1[6.7 \%]$ & 2 [13.3\%] & & \\
\hline & Leak during sex & $0[0.0 \%]$ & $1[6.7 \%]$ & & \\
\hline \multirow[t]{4}{*}{ Sexual function } & Vaginismus & $0[0.0 \%]$ & $4[26.7 \%]$ & & \\
\hline & Possible dyspareunia & $1[6.7 \%]$ & $3[20.0 \%]$ & & \\
\hline & Interference with sexual arousal & $0[0.0 \%]$ & $4[26.7 \%]$ & 20.28 & $<0.001^{* *}$ \\
\hline & Interference with sexual orgasm & $1[6.7 \%]$ & $3[20.0 \%]$ & & \\
\hline
\end{tabular}


DISCUSSION

Stress urinary incontinence [SUI] is reported among 13 to $46 \%$ of females at a young age. The rate increased if postmenopausal females were considered. It restricts the female quality of life due to affection to different aspects of life [e.g., sexual, physical, social and emotional aspects] [11]. Burch colposuspension is a well-accepted surgical technique for management of SUI. It was the gold standard intervention for a long time [open at first introduction followed by the laparoscopic technique] [12]. The TOT is a tension-free sling used also for treatment of SUI. Its main advantages are lower rate of de novo urge/urge incontinence. The sexual life [frequency, please or pain] is not affected [13].

The current work aimed to compare laparoscopic [Burch] colposuspension and TOT procedures for treatment of female SUI, regarding safety and efficacy. Analysis of our findings revealed that the majority of our patients were in their forties [40.17 \pm 13.01 vs $41.35 \pm 14.12$ in first and second groups]. No significant difference between the two groups was reported, regarding patient age, obesity or parity. In line with these results, Magon and Chopra [14] reported 46.2 years as the mean age of the females with SUI. Only 1 [1.7\%] was nulliparous, $13.6 \%$ were in primiparous and $84.7 \%$ were multiparous women. On the other side, Taweel and Rabah [15] reported 52 years, as a mean age of their patients, while Kaelin-Gambirasio et al. [16] reported an average age of 57.9 years. This explained by different sample size and inclusion criteria.

Regarding comorbidities, our results are in accordance with Elserafy et al. [17], where urinary incontinence was more prevalent among patients with hypertension and UTI. The percentage of patients with urge and mixed incontinence were significantly higher among the uncontrolled diabetic patients. Mixed incontinence was significantly related to constipation. Obesity was predominant among patients with stress.

Dean et al. [18] reported that, the advantages of laparoscopic colposuspension are rapid recovery when compared to traditional open approach, with comparable short and mid-term results. However, when laparoscopic Burch technique compared with recent 'self-fixing' sling maneuvers, the short term of the sling maneuvers provides greater benefits with similar, if not better cure rates.

Operative time was longer in the Burch than TOT groups. However, the difference was statistically non-significant. Magon and Chopra ${ }^{[14]}$ reported that the mean duration of TOT surgery was $21.69 \pm 6.41$ minutes. Otherwise, authors reported great variability in operative time. For example, Taweel and Rabah ${ }^{[15]}$ reported mean TOT surgery duration of 18 minutes.
Tan et al. [19] reported that laparoscopic colposuspension evades many disadvantages of open surgery. The cosmetic aspects of abdominal scar represented one of these advantages. Minimal invasive procedures allow shorter duration of the hospital stay, rapid recovery and return to normal daily activity. Results from the Cochrane review of Dean et al. [18] unsurprisingly, showed that laparoscopic intervention was associated with lower morbidity, a shorter duration of hospital stay, fewer postoperative complications, lower blood losses, shorter duration of catheterization, and significantly lower pain.

No significant differences were reported between the two groups for postoperative urgency, voiding dysfunction or de novo detrusor over-activity. McCormack et al. [20] reported that laparoscopic colposuspension have shown low perioperative comorbidities, longer operative duration, less pain, shorter hospital stay and a rapid overall recovery. Persson et al. [21] reported that laparoscopy has a longer operative and hospital stay durations and slower recovery of the normal daily activities. The one-year re-operation rates were reported in TVT procedures.

Purnichescu et al. [22] reported the mean hospital stay duration was 1.25 days in isolated TOT procedure. KaelinGambirasio et al. [16] reported a mean duration of 2.2 days. Furthermore, in the current study, we demonstrated that the major postoperative complications were bladder injury and wound infection among both groups, and there was nonsignificant difference between the two groups regarding any of postoperative complications. Magon and Chopra [14] reported that obstruction of the voiding dysfunction is the commonest complication of TVT. However, the TOT provides less chance for static urethral kinking and the urethral obstruction that may follow, due to transverse positioning.

TOT interventions are overall considered a harmless and effective procedure; however, there are many surgeryrelated comorbidities that must be considered. Perforation of bladder or vagina, formation of hematoma, neurological complications [numbness and weakness], pain, and mesh exposure as well as lower urinary tract complications [voiding dysfunction, new onset and persistent urgency urinary incontinence], are well documented [23].

Fusco et al. [24] in a systematic review compared TVT to TOT slings regarding complications, showed that, bladder/vaginal injuries favored TVT approach. Magon and Chopra [14] reported that, no one of their patients had neurological, vascular, or bowel injury. The most important step to avoid erosion and voiding dysfunction was found to be tape adjustment without any tension or any contact with the urethra. 
There were no complaints of thigh pain in our series, which confirms findings of a meta-analysis published in 2007 by Latthe et al. [25]; that the outside-in technique is usually not associated with this specific symptom. None of the patients had developed erosion, which was perhaps due to the use of non-woven, polypropylene mono filament with macro pores material to produce the tape. In another study of Persson [26], who compared 1-year cure rates after laparoscopic colposuspension using one double-bite or two single bite sutures on each urethral side, and reported that direct and long-term postoperative complications were few and self-limiting; with no difference between both techniques. However, one female developed pubic bone osteitis. She was treated conservatively by antibiotics [ciprofloxacin and clindamycin] for 4 weeks. Moreover, the current study revealed that there was non- significant difference between the two groups regarding functional and follow up outcomes. Albo et al. [27] reported that, success rates were higher for the pubovaginal sling compared to the Burch colposuspension [66\% vs. $49 \%$ ]; however, more females in the pubovaginal arm had UTIs, difficult voiding, and UUI. Other studies reported no significant difference in 18 months' cure rates. TOT was linked to shorter operative time, hospitalization, and time to resume normal activity [28].

Nilsson et al. ${ }^{[29]}$ published long-term results of the TVT technique for primary SUI from a multicenter study of 90 patients. $85 \%$ were cured, $10.6 \%$ were improved, and $4.7 \%$ were failed. There were no mesh erosions or permanent retentions. Laparoscopic colposuspension yielded similar results to those for TVT. Cure rates ranged between $69 \%$ and $100 \%$.

The limitations of our study include the short follow up period. It is still felt desirable that larger trials with bigger sample size and with a longer duration of follow-up for evaluating long-term success of TOT and laparoscopic Burch colposuspension are required. Further, comparative trials comparing TOT with other surgical options available for treatment of SUI shall be able to give it its right place of honor in the treatment of SUI. It has the possibility to be the new Gold Standard for treatment of female SUI.

\section{CONCLUSION}

In conclusion, the laparoscopic Burch colposuspension procedure resulted in significantly favorable outcome regarding cost, continence and sexual function. The complications were comparable between both procedures.

\section{Financial and Non-financial Relationships and Activities of Interest}

None

\section{REFERENCES}

1. Lovatsis D, Easton W, Wilkie D; UROGYNAECOLOGY COMMITTEE. Guidelines for the evaluation and treatment of recurrent urinary incontinence following pelvic floor surgery. J Obstet Gynaecol Can. 2010 Sep;32[9]:893-898. English, French. DOI: 10.1016/S1701-2163[16]34664-3.

2. Brown LK, Fenner DE, Berger MB, Delancey JO, Morgan DM, Patel DA, Schimpf MO. Defining patients' knowledge and perceptions of vaginal mesh surgery. Female Pelvic Med Reconstr Surg. 2013 Sep-Oct; 19 [5]: 282-7. DOI: 10.1097/SPV.0b013e31829ff765.

3. Lapitan MC, Cody JD, Grant A. Open retropubic colposuspension for urinary incontinence in women: a short version Cochrane review. Neurourol Urodyn. 2009;28[6]:47280. DOI: 10.1002/nau.20780.

4. Asicioglu O, Gungorduk K, Besimoglu B, Ertas IE, YIldırım G, Celebi I, Ark C, Boran B. A 5-year follow-up study comparing Burch colposuspension and transobturator tape for the surgical treatment of stress urinary incontinence. Int J Gynaecol Obstet. 2014 Apr;125[1]:73-7. DOI: 10.1016/j.jigo.2013.09.026.

5. Delorme E. La bandelette trans-obturatrice: un procédé miniinvasif pour traiter l'incontinence urinaire d'effort de la femme [Transobturator urethral suspension: mini-invasive procedure in the treatment of stress urinary incontinence in women]. Prog Urol. 2001 Dec;11[6]:1306-13. French. PMID: 11859672.

6. de Leval J. Novel surgical technique for the treatment of female stress urinary incontinence: transobturator vaginal tape insideout. Eur Urol. 2003 Dec;44[6]:724-30. DOI: 10.1016/j.eururo. 2003.09.003.

7. Rodrigues FR, Maroccolo Filho R, Maroccolo RR, Paiva LC, Diaz FA, Ribeiro EC. Pubovaginal sling with a low-cost polypropylene mesh. Int Braz J Urol. 2007;33[5]: 690-4. DOI: 10.1590/s1677-55382007000500011.

8. Freites J, Stewart F, Omar Ml, Mashayekhi A, Agur WI. Laparoscopic colposuspension for urinary incontinence in women. Cochrane Database Syst Rev. 2019;12[12]: CD002239. DOI: 10.1002/14651858.CD002239.pub4.

9. Kalejaiye $\mathrm{O}, \mathrm{Vij}$ M, Drake MJ. Classification of stress urinary incontinence. World J Urol. 2015 Sep;33[9]:1215-20. DOI: 10.1007/s00345-015-1617-1.

10. Chinthakanan O, Miklos JR, Moore RD. Laparoscopic Paravaginal Defect Repair: Surgical Technique and a Literature Review. Surg Technol Int. 2015 Nov; 27:173-83. PMID: 26680393.

11. Glazener CM, Cooper K, Mashayekhi A. Anterior vaginal repair for urinary incontinence in women. Cochrane Database Syst Rev. 2017 Jul 31;7[7]:CD001755. DOI: 10.1002/14651858. CD001755.pub2. 
12. Mazur-Bialy Al, Kołomańska-Bogucka D, Nowakowski C, Tim S. Urinary Incontinence in Women: Modern Methods of Physiotherapy as a Support for Surgical Treatment or Independent Therapy. J Clin Med. 2020 Apr;9[4]:1211. DOI: 10.3390/jcm9041211.

13. Haylen BT, de Ridder D, Freeman RM, Swift SE, Berghmans $\mathrm{B}$, Lee J, et al. International Urogynecol-ogical Association; International Continence Society. An International Urogynecological Association [IUGA]/ International Continence Society [ICS] joint report on the terminology for female pelvic floor dysfunction. Neurourol Urodyn. 2010;29[1]:4-20. DOI: 10.1002/nau.20798.

14. Magon N, Chopra SV. Transobturator Tape in Treatment of Stress Urinary Incontinence: It is Time for a New Gold Standard. N Am J Med Sci. 2012 May;4[5]:226-30. DOI: 10.4103/1947-2714.95905.

15. Taweel WA, Rabah DM. Transobturator tape for female stress incontinence: follow-up after 24 months. Can Urol Assoc J. 2010 Feb;4[1]:33-6. DOI: 10.5489/cuaj.08118.

16. Kaelin-Gambirasio I, Jacob S, Boulvain M, Dubuisson JB, Dällenbach P. Complications associated with trans-obturator sling procedures: analysis of 233 consecutive cases with a 27 months' follow-up. BMC Womens Health. 2009;9:28. DOI: 10.1186/1472-6874-9-28.

17. Elserafy FA, Shaheen HM, Khalil NA, M. Abdelrahman HA. Urinary incontinence among elderly women attending a rural family health center in Gharbiya Governorate, Egypt. Menoufia Med J 2019; 32:955-960. DOI: 10.4103/mmj.mmj_701_17

18. Dean N, Ellis G, Herbison GP, Wilson D, Mashayekhi A. Laparoscopic colposuspension for urinary incontinence in women. Cochrane Database Syst Rev. 2017; 7[7]: CD002239. DOI: 10.1002/14651858.CD002239.pub3.

19. Tan E, Tekkis PP, Cornish J, Teoh TG, Darzi AW, Khullar V. Laparoscopic versus open colposuspension for urodynamic stress incontinence. Neurourol Urodyn. 2007;26[2]:158-69. DOI: 10.1002/nau.20398.

20. McCormack K, Scott NW, Go PM, Ross S, Grant AM; EU Hernia Trialists Collaboration. Laparoscopic techniques versus open techniques for inguinal hernia repair. Cochrane Database Syst Rev. 2003; [1]: CD001785. DOI: 10.1002/14651858. CD001785.

21. Persson J, Teleman P, Etén-Bergquist C, Wølner-Hanssen P. Cost-analyzes based on a prospective, randomized study comparing laparoscopic colpo-suspension with a tension-free vaginal tape procedure. Acta Obstet Gynecol Scand. 2002; 81[11]:1066-73. DOI: 10.1034/j.1600-0412.2002.811112.x.
22. Purnichescu V, Cheret-Benoist A, Eboué $C$, Von Theobald P. [Surgical treatment for female stress urinary incontinence by transobturator tape [outside in]. Study of 70 cases]. J Gynecol Obstet Biol Reprod [Paris]. 2007 Sep;36[5]:451-8. DOI: 10.1016/j.jgyn.2007.04.001.

23. Ellington DR, Erekson EA, Richter HE. Outcomes of Surgery for Stress Urinary Incontinence in the Older Woman. Clinics Geriatric Med 2015; 31[4]: 487-505. [English Abstract] DOI: 10.1016/ j.cger. 2015.06.006.

24. Fusco F, Abdel-Fattah M, Chapple CR, Creta M, La Falce S, Waltregny D, Novara G. Updated Systematic Review and Meta-analysis of the Comparative Data on Colposuspensions, Pubovaginal Slings, and Midurethral Tapes in the Surgical Treatment of Female Stress Urinary Incontinence. Eur Urol. 2017 Oct;72 [4]: 567-591. DOI: 10.1016/j.eururo.2017.04.026.

25. Latthe PM, Foon R, Toozs-Hobson P. Transobturator and retropubic tape procedures in stress urinary incontinence: a systematic review and meta-analysis of effectiveness and complications. BJOG. 2007; 114[5]:522-31. DOI: 10.1111/j.1471-0528.2007.01268.x.

26. Persson J, Wølner-Hanssen P. Laparoscopic Burch colposuspension for stress urinary incontinence: a randomized comparison of one or two sutures on each side of the urethra. Obstet Gynecol. 2000 Jan;95[1]:151-5. DOI: 10.1016/s00297844[99]00529-3.

27. Albo ME, Richter HE, Brubaker L, Norton $P$, Kraus SR, Zimmern PE, et al.; Urinary Incontinence Treatment Network. Burch colposuspension versus fascial sling to reduce urinary stress incontinence. N Engl J Med. 2007 May 24;356[21]:214355. DOI: 10.1056/NEJMoa070416.

28. Veit-Rubin N, Dubuisson J, Ford A, Dubuisson JB, Mourad S, Digesu A. Burch colposuspension. Neurourol Urodyn. 2019;38[2]:553-562. DOI: 10.1002/nau.23905.

29. Nilsson CG, Kuuva N, Falconer C, Rezapour M, Ulmsten U. Long-term results of the tension-free vaginal tape [TVT] procedure for surgical treatment of female stress urinary incontinence. Int Urogynecol J Pelvic Floor Dysfunct. 2001; 12 Suppl 2: S5-8. DOI: 10.1007/ s001920170003. 


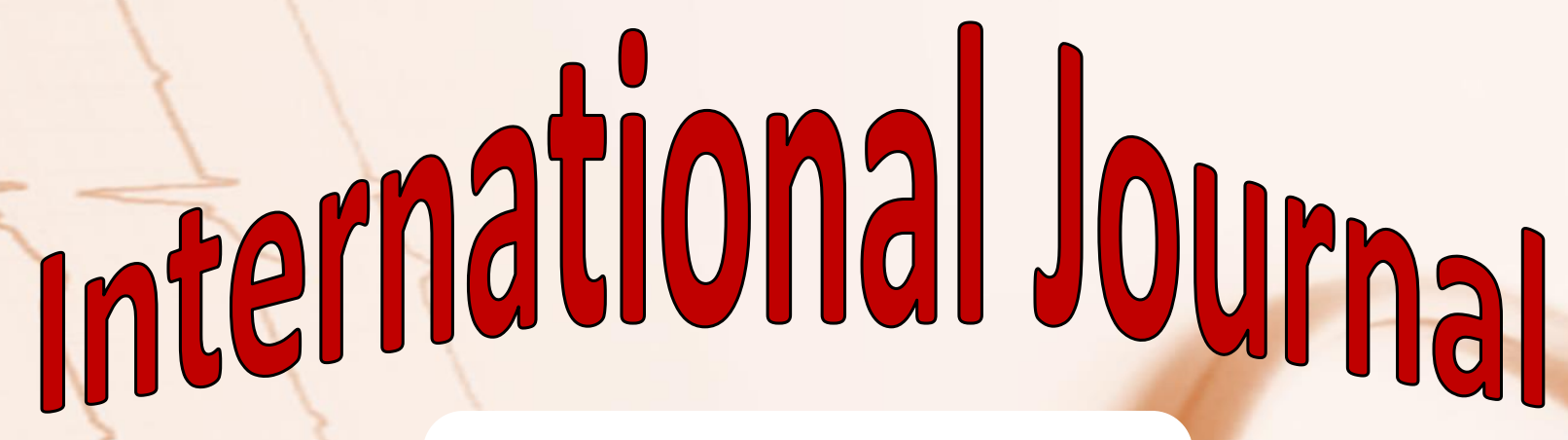

https://ijma.journals.ekb.eg/ Print ISSN: 2636-4174 Online ISSN: 2682-3780

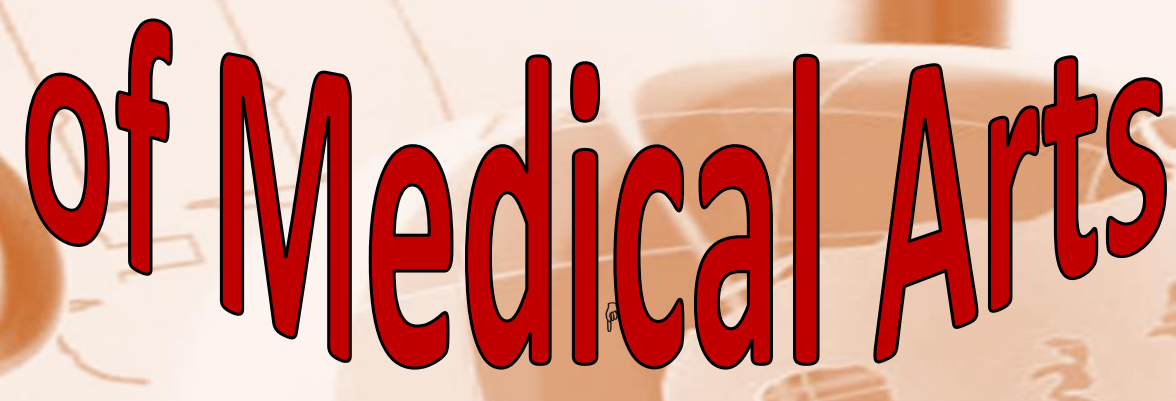

